\title{
Biological production of hydrogen from glucose by natural anaerobic microflora
}

\begin{abstract}
Palm oil mill effluent (POME) sludge, sludge compost from Malaysia and CREST compost from Philippines were collected for the study. The capability of these microflora to produce hydrogen was examined with $500 \mathrm{ml}$ artificial wastewater containing $1 \%$ glucose, $0.2 \%$ yeast extract and $0.018 \%$ magnesium chloride hexahydrate under anaerobic fermentation in a batch culture. The microflora in POME sludge, sludge compost and CREST compost were found to produce significant amounts of hydrogen. The maximum production yield of hydrogen per decomposed glucose was $2.1 \mathrm{~mol} / \mathrm{mol}$-glucose at a conversion rate of $0.137 \mathrm{~L} /(\mathrm{L}-\mathrm{medh})$ at $50^{\circ} \mathrm{C}$ obtained by sludge compost. All fermentations were carried out without $\mathrm{pH}$ control. It was also found that the addition of nitrogen source in the medium caused a change in hydrogen produced. There was no methane gas in the evolved gas.
\end{abstract}

Keyword: Hydrogen production; POME sludge; Sludge compost; CREST compost; Microflora 